\section{Task force set up to combat threat of political interference}

Erika Check, Washington

One of the largest health-research institutes in the Unites States has set up an informal task force to monitor political threats to its funding.

Al Sommer, dean of the Johns Hopkins Bloomberg School of Public Health in Baltimore, Maryland, has assembled a committee to collect information about a 'hit list' of grants funded by the US National Institutes of Health (NIH). Four members of the school's faculty were named in the list, which was given to a US congressional committee by a religious lobby group.

The move by Hopkins researchers shows how deeply the issue has affected the research community. The lobby group has urged lawmakers to withdraw funding for the grants on its list, which include research on topics such as drug use, prostitution and homosexuality.

Congress has so far not revoked funding. But this July, the legislature narrowly voted down an attempt to halt funds for a smaller set of NIH-funded projects, so scientists are taking the 'hit list' seriously.

Sommer says that the four-person task force at the school of public health will "serve as a focal point through which faculty and students can report instances about which they might be concerned", such as phone calls from federal officials or the media. Although the task force has not decided to lobby, Sommer does not rule out further action. "We're trying to collate what's happening so we can form an institutional response," he says.

Hopkins gets more NIH funding than any other establishment of its type. Last year it received $\$ 88$ million from the NIH $-44 \%$ of its research money, and about a quarter of its total budget.

So far, no other institution has taken such an organized approach, although many have been affected. The University of California, for instance, had 31 researchers on the list. But Robert Dynes, president of the University of California, has written to the state's congressional delegation on behalf of its researchers, some of whom think that this will head off the political threat.

"We have faith in the peer-review process, and that it will ultimately be viewed as an objective way of considering what is proper science," says Cynthia Gómez, co-director of the Center for AIDS Prevention Studies at the University of California, San Francisco.

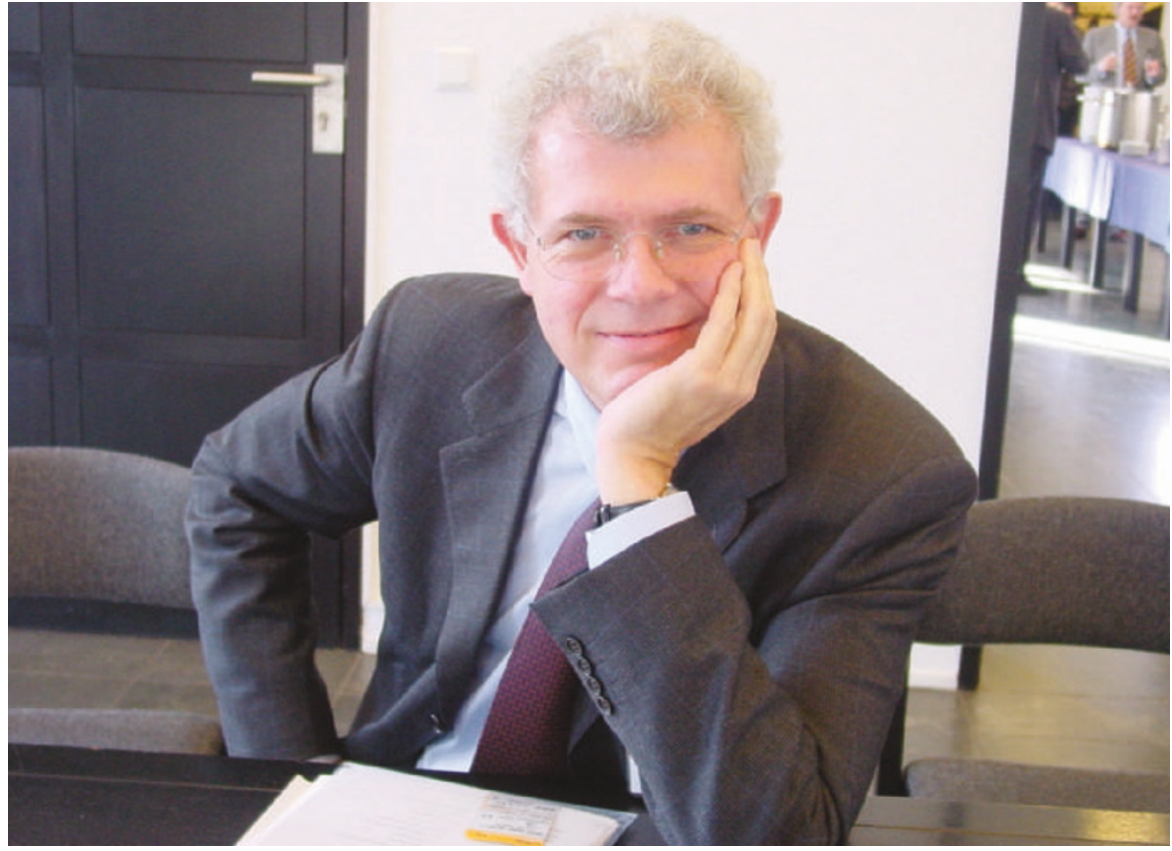

Hans-Heinrich Trute: rules made to protect the accused leave those who speak out in danger.

\title{
Whistles blow in vain on bad practice in German research
}

\section{Alison Abbott, Bonn}

In summer last year, a consultant dermatologist at the University of Göttingen's skin clinic was stripped of responsibilities and demoted to a technical position. His crime? Pointing out that a patient in a neurodermatitis therapy test, which was deemed successful, had been symptomless before the treatment was given. Blowing the whistle on research misconduct can be a dangerous game in Germany.

Such incidents were on the minds of university ombudsmen from across Germany who gathered in Bonn last week to review their progress in stamping out misconduct. Many of them said that whistleblowers remain poorly protected in Germany, and that sloppy research practices, particularly in the clinical arena, are still rife.

The ombudsmen were hired as part of an effort by the DFG, the German research funding agency, that began in earnest in 1997, when a serious fraud case emerged involving two clinical researchers who fabricated or manipulated data in nearly 100 papers (see Nature 405, 871-872; 2000).

Back then, the DFG issued guidelines stating that universities should teach the rules of scientific good practice, appoint ombudsmen to act as independent mediators in cases of conflict and establish procedures for investigating such allegations.

By 2001 it had to threaten to withhold funding from non-complying institutions. The DFG also appointed three ombudsmen of its own, to whom scientists can turn if they do not want to discuss their concerns locally.

These catalogued 74 cases during 2001 and 2002; no one has yet tallied the number handled by university ombudsmen. Most concerned disputes over authorship, with disputes over access to data, accusations of data manipulation, and alleged blocking of an individual's career also figuring prominently. Only a couple of cases were referred to formal investigation committees.

The DFG ombudsmen's cases have been published (without naming individuals) at www.rrz.uni-hamburg.de/dfg_ombud. This measure will now be extended to university ombudsmen.

But the Bonn meeting exposed many frustrations, particularly about protection of whistleblowers. "Rules were designed with protection of the accused in mind," says DFG ombudsman Hans-Heinrich Trute, a law professor at the University of Hamburg. A working group will now be set up to make recommendations on protecting whistleblowers. One possibility, says Trute, could be to require universities to track their subsequent career paths, to highlight any attempt to undermine or demote them.

"The sloppiness in clinical research is so vast that we need to be looking at very serious preventive measures," says Irmelin Probst, an ombudswoman at the University of Göttingen, which has been hit by more clinicalresearch scandals than any other German institute. "The extreme hierarchy in oldfashioned clinical departments, and ignorance about research methods among older clinical scientists, is to blame," she adds.

Ombudsmen at the meeting pledged to persuade more universities to teach good scientific practice. 